\title{
Critical Literacy with (Freire) and for the Other (Levinas): Ethics/Social Justice as Enigmatic Becoming
}

\section{Letramento Crítico com (Freire) e para o outro (Levinas): éticas/justiça social como vir a ser enigmático}

Nara Hiroko Takaki*

*Universidade Federal do Mato Grosso do Sul (UFMS), Campo Grande, Mato Grosso do Sul / Brasil

narahi08@gmail.com

https://orcid.org/0000-0001-8574-5842

\begin{abstract}
One of the key features of critical literacy is the concern with the human and non-human collective other in vulnerable social condition. The obstruction for disenfranchised communities, local language policy goals, exacerbating social inequities and violence seems never-ending. Much before the pandemic times, one side of society had been forcing unprivileged and disempowered communities to struggle for alternative ways to go on playing the game of life. To this end, innovative, participative and ethical education which places the self as responsible for the radical other, frequently an enemy, (LEVINAS, 2007) might enhance learning, unlearning and relearning. I conclude that such a perspective might expand the exercise of critical literacy (FREIRE, 2005), a condition to minimize the impacts of the crises in contemporary society. This research is part of my ongoing project entitled Linguistic-Cultural Education, Language Teaching, Technologies and productive Social Justice in Dilemmatic Times and it is linked to the National Project of Teacher Education ${ }^{1}$ through the theories of Critical Literacies, Multilteracies, New Literacies, coordinated by Walkyria Monte Mór and Lynn Mario Trindade Menezes de Souza. Following a bibliographic interpretive research methodology, this work comprises two moments. In the first one, it presents a brief outline of the already one with and for the other in contemporary scenario of online/
\end{abstract}

${ }^{1}$ USP (2015-2021). Universidade de São Paulo. Projeto Nacional de Letramentos: Linguagem, Cultura, Educação e Tecnologia. Available at: http://letramentos.fflch.usp. br/sobre. Access on: 20 May 2020. 
offline learning, intertwined with the current educational Brazilian situation, going beyond (post)pandemic times, as life-long learning (ALHEIT, 2018). The second moment seeks to theorize on the contributions of Freire (2005), Levinas (1991, 1994, 2000, 2007, 2008, 2014) and Braidotti (2006, 2018, 2019) with more details on the second, bearing in mind the Levinasian ethics is apparently less approached in the applied field of linguistics and also due to the scope of this article.

KEYWORDS: language; critical education; society; teacher education.

RESUMO: Um dos aspectos chave do letramento crítico é a preocupação com o outro coletivo, humano e não humano, em condição vulnerável. A obstrução para comunidades marginalizadas, objetivos de políticas linguísticas locais exacerbando desigualdades sociais e violência parecem intermináveis. Muito antes dos tempos pandêmicos, um lado da sociedade vem forçando comunidades desprivilegiadas e desempoderadas a lutar por alternativas para jogar o jogo da vida. Para tal finalidade, uma educação inovadora, participativa e ética que posicione o eu como responsável pelo outro, frequentemente um inimigo, (LEVINAS, 2007) pode ampliar aprendizagem, desaprendizagem e reaprendizagem. Concluo que essa perspectiva pode expandir o exercício do letramento crítico (FREIRE, 2005), uma condição para minimizar os impactos das crises na sociedade contemporânea. Esta pesquisa é parte de meu projeto em andamento e intitulado Educação Linguística-Cultural, Ensino de Línguas, Tecnologias e Justiça Social Produtiva em Tempos Dilemáticos e está vinculado ao Projeto Nacional de Formação de Professores pelas teorias de Letramentos Críticos, Multiletramentos e Novos Letramentos, coordenado pela Profa. Dra. Walkyria Monte Mór e pelo Prof. Dr. Lynn Mario Trindade Menezes de Souza. Seguindo uma metodologia bibliográfica e interpretativista, este trabalho compreende dois momentos. O primeiro momento apresenta um breve esboço do já com um e para o outro no cenário online/off-line contemporâneo, interconectado à situação atual da educação brasileira, indo além do tempos (pós)pandêmicos, como aprendizagem para vida (ALHEIT, 2018). O segundo busca teorizar as contribuições de Freire (2005), Levinas (1991, 1994, 2000, 2007,2008 , 2014) e Braidotti $(2006,2018,2019)$ com mais detalhes no segundo, tendo em mente que a ética Levinasiana é menos abordada no campo aplicado da linguística e também pelo escopo deste artigo.

PALAVRAS-CHAVE: linguagem; educação crítica; sociedade; formação de professor. 


\section{An outline of the already one with and for the other in updated online/offline spaces ${ }^{2}$}

Looking back at the Brazilian history, one soon perceives that addressing issues of colonial othering entrenched in schooling remains central in the reconstruction of education and society much before the COVID-19 pandemic, at least in Paulo Freire's land. The dominant white Eurocentric culture has been proving to be a mechanism for social (re) production in many parts of Brazil and in the world. The advent of the COVID-19 pandemic has only leveraged more social inequalities.

Horizontal relations have interweaved regions and communities on one hand, but on the other, vertical mechanisms, such as gatekeeping still persists. The long-standing colonial matrix of power (QUIJANO, 2005) with a focus on questions of race (the hallmark of the West), gender, class, religion appears to be a far-cry from identity, social justice reconstruction. Advocating for the unpacking of the white privilege online/offline from alterity (LEVINAS, 2007) might be a good start.

We also have witnessed competing views in relation to the validity of emergent education in Brazil. Great precarity, in particular, lack of technological resources leaving innumerous students behind with teachers having to become YouTubers overnight calls for further responsibility for the other (LEVINAS, 2000, 2008). It encompasses collaboration, critique, creativity and ethics on the part of the authorities, community members and individuals all together.

Now, I briefly outline the already one with and for the other in contemporary scenario of online/offline learning intertwined with the current educational Brazilian scenario, going beyond (post)pandemic times as life-long learning (ALHEIT, 2018). Then, I theorize the contributions of Freire (2005), Levinas (1991, 1994, 2000, 2008, 2014) and Braidotti (2006, $2018,2019)$ for critical literacy, with more details on the second bearing in mind the Levinasian ethics is apparently less approached in the applied field of linguistics and also due to the scope of this article.

\footnotetext{
${ }^{2}$ The aim of this section is to set the scene in which critical literacy with (with presupposes against due to difference/alterity) and for the other, as ethics/ social justice may/might be already happening/becoming in many contexts and, in subsequent sections, I will seek to detail the theoretical background, which justifies the title of this paper.
} 
It has been perceived that our condition with each other to build up connections is not new. The digital medium has accelerated the encounter of simultaneous social, cultural and ideological constructions on a daily basis in situated diverse ways. Being, staying with and transforming issues in place begins with a concern with the discrepancy of social inequalities and structures. Social inequities are bound to language use, according to Freire (2005), Janks (2010), Luke (2019), Muspratt, Luke and Freebody (1997), Monte Mór (1999, 2008, 2010, 2011, 2013, 2017a, 2017b, 2018, 2019), Souza (2019), Pennycook (2006, 2018), Pennycook and Makoni (2020) to name a few. Specific language uses place disenfranchised people in disadvantageous situations in life. Fortunately, the heterogeneous nature of language (VOLÓCHINOV, 2017) permits people to challenge, resist and reconstruct the apparent reality from the text/event/life. ${ }^{3}$

"The project of decolonizing new media is timely, considering that the field is coextensive with corporate and institutional interests that make it indispensable for economic growth and the war on terror"4 (BRAIDOTTI, 2019, p. 163). While decolonial artificial intelligence within continuous reflexive (self)critique (TAKAKI, 2019, 2020) is nonexistent to decolonize artificial intelligence that support neo-liberalism, more emphasis on critical literacy is desirable and needed. To this end, reading the world and the word in Freirean terms requires reinventions of education. After all, "there is no education without creativity" (FREIRE, 2005, p. 299), which "is constructed while I risk to create, to expose myself, while am not afraid of making mistakes", complements Freire, (2005, p. 299).

Family members are no longer intruders: they have recruited themselves to provide their children/friends with some support to attend online classes and also participate actively as intended audience. Houses have become post-digital environment (with non-human crucial functions, in BRAIDOTTI'S view, 2018, 2019) at least for those people who can afford to maintain infrastructure, technological scaffolds mixed (or not) with "digital epistemology" (LANKSHEAR; KNOBEL, 2002, p. 5) or "performance epistemology" (LANKSHEAR, KNOBEL, 2011, p. 11) more pertinent to

\footnotetext{
${ }^{3}$ From now onwards, event.

${ }^{4}$ Evidence of this need is the documentary The Social Dilemma, directed by Jeff Orlowski, on Netflix. It refers to a documentary raising concerns about the impact of social media and search platforms on democracy. Source: www.thesocialdilemma.com/.
} 
any ${ }^{5}$ pandemic time, in a metaphorical sense. This brings us to the next key point: the fact that digital epistemology has been exercised by more or less skilled parents/partners, under specific contextual circumstances, to help their children, children's friends cope with emergent education. ${ }^{6}$ But, what is digital epistemology, after all?

More than propositional knowledge of what already exists, much of the knowing that is involved in the new spaces might better be understood in terms of a performance epistemology - knowing as an ability to perform - in the kind of sense captured by Wittgenstein as: 'I now know how to go on.' This is knowledge of how to make 'moves' in 'language games.' It is the kind of knowledge involved in becoming able to speak a literal language, but also the kind of movemaking knowledge that is involved in Wittgenstein's notion of language as in 'language games' (WITTGENSTEIN 1953, apud LANKSHEAR, KNOBEL, 2002, p. 11).

Digital epistemology, from such authors' views, refers to the idea that navigation lays emphasis on the building of intuitive knowledge, learning by trial and error in an interest-driven digital space, a characteristic of the Freirean notion of learning. While digitally performing, neither do students, parents, partners, teachers necessarily apply existing world view in this enterprise, nor do they have to rely on lived experience to proceed in co-constructing, circulating and renegotiating knowledge and power. Transferable literacies and the exploration of alternative styles for the students to move ahead with the goal of solving daily problems seem to be on the way.

\footnotetext{
${ }^{5} \mathrm{Had}$ it not been for the Government's lack of investment in public education providing schools with continuous updated teacher education, resources (ICT), technical maintenance, efficient/fast/free access to the Internet, basic sanitation, health and public transportation including the remote areas, the impact would be less serious for the country. The COVID-19 pandemic has intensified such issues.

${ }^{6}$ Clearly, carrying out ethnographic research in diverse urban and rural Brazilian areas would be necessary to investigate how parents have been (or not) creating space for their children to make critical, creative and ethical meanings within their lessons in transcultural and transdisciplinary ways.
} 
Hence, a particular 'assemblage' of knowledge that is brought together-however momentarily- in the product of an individual may more properly be understood as a collective assemblage involving many minds (and machines) (LANKSHEAR, 2003, p. 11).

Hinted in this citation is an ethical posthumanist approach (BRAIDOTTI, 2019) expanding Applied linguistics (PENNYCOOK, 2018), whose main tenet is the notion that the centrality of human agency has been undermined leaving space for the functions of nonhuman beings, such as: objects, plants, environment, spatiality resembling an assemblage. "These complex posthuman ensembles that constitute subjectivity are negotiable: the 'human' is just a vector of becoming. 'We' need to compose a new people and a new earth.” (BRAIDOTTI, 2019, p. 168). As cultural agents within creative, critical and contingent modes of participation, students, now and then, have (or not) companions (the Freirean, Levinasian and Braidottian pluralized other): parents and other partners, objects, machines, spatiality, connection, more (or not so much) distributed relations of power ${ }^{7}$ which interfere and intervene in the coconstruction of knowledge (BRAIDOTTI, 2018, 2019; CANAGARAJAH, 2013; 2017; PENNYCOOK, 2018). No doubt, this represents a significant paradigm shift in the status of knowledge construction and agency requesting further understanding of the other (LEVINAS, 2000), as argued here. Capitalizing on this new spatio-temporal condition (CANAGARAJAH, 2017) seems to be productive. Consequently, teacher and community members' continuous education informed by the inseparability of updated ontology-epistemology-methodology ${ }^{8}$ (TAKAKI, 2016) is likely to reconnect joint effort and widen life chances. Life chances mainly for the other (LEVINAS, 2000), the "missing people" as Braidotti (2019, p. 169) points out, which means the marginalized people, animals,

\footnotetext{
${ }^{7}$ One of my undergraduate students said some of her students' parents are not patient enough to help their children during emergent education. Such students have been missing classes and they will probably restart them only in 2021.

${ }^{8}$ Ontology-epistemology-methodology in rhizomatic ways is close to the notion of assemblage (CANAGARAJAH, 2013). Reflexive autoethnography/selfcritique is illustrative of this premise. For additional information, see Takaki (2020). "The autoethnography where the auto is a collectivity and mediated on top of it" as postulated by Braidotti (2018, p. 185).
} 
plants, objects, affections, and the not yet known, since ethics/social justice is more congruent to a process of enigmatic becoming.

How ubiquitous learning happen in more or less privileged and vulnerable homes together with a reflection upon the consequences in specific communities have yet to be investigated. In such contexts, contributors from diverse fields tend to bring their repertoires to reinvent learning in quarantine, which means knowledge construction has counted on distributed performativity. Non-academic members might resort to social literacy (STREET, 2014) and see themselves more closely linked to the teachers, spending time with and understanding them, showing respect and solidarity. This perception in tune with online/offline learning, intertwined with the current educational Brazilian scenario, already reflects an ethical relationship: that of with one for the other and might represent some small but significant gains in terms of life-long learning (ALHEIT, 2018) and enhance opportunities for transdisciplinary and transcultural online/ offline engagement before, during and after the navigations or face-toface interactions. In other words, social justice might start at home and go unnoticed even in times of crises.

When participants enter the digital world, (in)directly, they are led to engage in complex semiotic landscape (CANAGARAJAH, 2017; PENNYCOOK, 2020) permeated with a range of dynamic multimodes blending materials, objects, emotions, synesthesia, criss-crossed contexts, spatio-temporal elements and contingencies which characterize the complexity of an assemblage going beyond mere multimodality, as claimed by Canagarajah (2017). "Communication media as a rhizomatic assemblage can be exploited considering the 'subtle machinations of power"' (CANAGARAJAH, 2020, p. 9). I understand that rhizomatic power allows for resistance and possibilities at the same time, though. Unlike Deleuze and Guattari (2005), for whom a rhizome is a better metaphor than a tree, I consider a tree as complex as a rhizome, drawing on Monte Mór (2011). Such authors might have not known a rhizome is also a root. Since it is very easy to domesticate both, what really matters is the way we promote the "deconstruction of the interpretive habitus" (MONTE MÓR, 2017b, p. 324), that is, the way we attribute meanings to either a rhizome or a tree, social justice, life. Hence, it is pivotal to exercise reflexive selfcritique to reinterpret a rhizome, a tree, an assemblage as the "infinite other" (LEVINAS, 1994, 2008), This other is the human, non-human and 
in-human in Braidotti's affirmative ethics (2019), which is explained in more details subsequently. In socionatural practices (BARAD, 2007), material agents other than human ones do matter for performativity. "The material and the discursive are mutually implicated in the dynamics of intra-acting" (BARAD, 2007, p. 152). Environments, matters, and the bodies are intraactively constituted always evolving and becoming, which is a timeless and key point to foster the integration of technology, education and society. Indeed, premature and immediate evaluations of the emergent education might overlook such aspects. Further research is desirable and needed here.

Having outlined some hints related to the already one with and for the other, the next sections aim at going beyond (post)pandemic times, while ressignifying critical literacy. At the same time, a question that has arisen in this landscape is: How can critical literacy be revisited to cope with online/ offline education?

It counts on the Freirean relationship between the self/eu and the other/tu (with the other), on Levina's (2008) philosophical ethics (the self/ one for the other) within Braidotti's $(2018,2019)$ ethics of affirmation, which revitalizes social justice in entangled ways including otherness, diversity and the inside-outside contexts. This is the subject-matter of the next section.

\section{Critical literacy with and for the other}

Tu me ensina a fazer renda Que eu te ensino a namorá

(Demônios da Garoa)

"You teach me lace making and I teach you to date" is a rough translation of the above quotation, to which Monte Mór ${ }^{9}$ referred while explaining the complicity in language teaching, learning, in short, teacher education.

Teacher and student's critical education (FREIRE, 2005) constitutes one of the most relevant concerns in society. If education is a political act, some questions remains to reimagine critical linguistic education: How can critical literacy be revisited within emergent education? Who decides and under whose interests (FREIRE, 2005; JANKS, 2010; LUKE, 2019;

${ }^{9}$ This was said while she lectured at the University of São Paulo, in 2017. 
MUSPRATT; LUKE; FREEBODY, 1997; MONTE MÓR, 1999, 2008, 2010, 2011, 2013, 2017a, 2017b, 2018, 2019). Another theorist has been asking: "Are we really indigenizing academia successfully or are we simply trying to academize indigeneity?" (SCHMIDT, 2020, p. 6). What conception of reading matters considering it is not self-contained but rather engraved in cultural, historical, political and economic perspectives?

Rather than reinforcing the dichotomy between good and bad revolving around education in a broader sense (emergent, homeschooling, distant learning, face-to-face teaching), interrogating how students' make meanings in ways to respond to the demands of complex, paradoxal, and increasingly heterogeneous society is desirable and needed. "The critical reading of texts and of the world has to do with its change in progress" 10 (FREIRE, 2001, p. 268). Within this paradigm, envisioning possibilities entails awareness that a significant shift:

[...] consists in the practice I have been referring to as 'reading of the reading prior to the world', understood as 'reading of the world' the 'reading' that precedes the reading of the word and that following equally the understanding of the object in the realm of the everyday. The reading of the word, in search for the understanding of the text, and therefore, of the objects referred to in it, lead us to the reading prior to the world. What seems fundamental to make clear is that the reading of the world, which is done through sensorial experience does not suffice. But, on the other hand, it cannot be regarded as inferior by the reading done through the abstract world of conceptions, which goes from generalizations to manifestations ${ }^{11}$ (FREIRE, 2001, p. 261).

\footnotetext{
${ }^{10}$ Our translation from: A leitura crítica dos textos e do mundo tem que ver com a sua mudança em processo.

${ }^{11}$ Our translation from: consiste na prática que me venho referindo como "leitura da leitura anterior do mundo", entendendo-se aqui como "leitura do mundo" a "leitura" que precede a leitura da palavra e que per-seguindo igualmente a compreensão do objeto se faz no domínio da cotidianidade. A leitura da palavra, fazendo-se também em busca da compreensão do texto e, portanto, dos objetos nele referidos, nos remete agora à leitura anterior do mundo. $\mathrm{O}$ que me parece fundamental deixar claro é que a leitura do mundo que é feita a partir da experiência sensorial não basta. Mas, por outro lado, não pode ser desprezada como inferior pela leitura feita a partir do mundo abstrato dos conceitos que vai da generalização ao tangível.
} 
This quotation is a lesson for life-long learning (ALHEIT, 2018). In Freirean terms, the social, cultural, political forces that influence the context from/with which our interpretations are constructed need to be questioned and resignified permanently. Proceeding in this way, new horizons tend to emerge as we see things differently with revitalized lenses from one situation to another. Reassessing world views is prior to any encounter with a particular text. Our historical and sociocultural experience are carried by meanings which are reconstructed each time we try to struggle for the understanding of ourselves and of the other(s) reflexively within societal forces.

Everyday life entails situated ubiquitous learning, in which particular historical, cultural, political positions and embodied forms of intersubjectivities are overlapped. When students' inter-subjectivities are reshaped by neoliberal forces, their meaning making can hardly distance from the ideological market orientation. A critical revision of the larger contexts in which they construct and articulate discourses, make decisions and participate in the social world calls for the reasserting of the principles of democratic, qualitative, state education for all.

By the same token, an educational reform should warrant

critique while we try to find productive and agentive pathways through, around, within and against it for ourselves and our students, and maintenance of a strong, equitable civic sphere and ongoing radical social transformation (LUKE, 2019, p. 160).

As clearly stated, critique plays a central role in the reinvention of school towards legitimized participation of the "missing people" (BRAIDOTTI, 2019, unpaged) - at the risk of being repetitive here-. To sharpen meanings, a more detailed and sophisticated sociocultural, economic analysis encompassing available and contingent forms of capitals is required in literacy education.

Literacy-in-education, language-in-education, and curriculum policies designed to ameliorate or modify the socioeconomic, cultural and social disadvantage experienced by those students, need to extend beyond the school to ensure that the viable conditions for the use and exchange of that capital is possible and probable[...] Social, economic and literacy education policies must work synergistically (LUKE, 2019, p. 187). 
Drawing on this orientation, continuous teacher education in pandemic and future times, requires "forms of intercultural capital" (LUKE, 2019, p. 160). Putting it differently, the capacity to engage in acts of knowledge, power and exchange across time-space "divides" and social geographies, across diverse communities, populations and epistemic stances, following the cited author's lessons (2019, p. 169).

Made evident here is the recognition of teaching as a dynamic arena of conflicts. It goes hand-in-hand with the Freirean reminder of an intellectual routine, for "studying is a preparation to get to know, it is a patient and impatient exercise of one who, not aiming at all at once, struggle for knowing"12 (FREIRE, 2001, p. 266).

In pedagogical meetings with the principals, coordinators, students, teachers, community members and policy makers can/should invite professionals of diverse field of knowledge to exercise the digital epistemologies (LANKSHEAR, 2003) as previously emphasized. Also crucial is to make such people conscious of the active role of the reader and that "reading is tied up in the politics and power relations of everyday life in literate cultures" (MUSPRATT; LUKE; FREEBODY, 1997, p. 185), and ask themselves: What kind of individual and society are implied when choices are made based on such theoretical-practical particular views? Being able to translate culturally and pedagogically the above question to parents shows respect and sensibility towards the Freirean, Levinasian and Braidottian pluralized other.

Another key point is the possibility of bringing in to the classroom routine, indigenous, migrants' knowledge, experience, linguistic resources, strategies and abilities gained through technical, manual, agricultural, house work and the like. In this way, a sense of collaboration in teaching with the inclusion of social literacy (STREET, 2014) is dislocated from invisibility to a productive public stage in which the distribution of power and knowledge reconstruction might be fostered.

Many housewives exercise critical literacy by reading labels in supermarkets and know who are and who are not able to purchase certain products, as highlighted by Monte Mór in her classes. Awareness of power as one aspect of social inequity is implied here. Simple examples from everyday

\footnotetext{
${ }^{12}$ Our translation from: estudar é uma preparação para conhecer, é um exercício paciente e impaciente de quem, não pretendendo tudo de uma vez, luta para fazer a vez de conhecer.
} 
life to reflect upon the participants' agency can be incorporated in schooling and be extended locally by community mobilization and their combinatory potentials, values and strategies. ${ }^{13}$

"Literate" participants can learn with otherness experimenting the notion that "reading is about reading cultures and worlds" (FREIRE, 2002, p. 201). Undermining conservative set of beliefs, values and social practices from the neo-liberal Global North can be envisioned to purposely empower apparent vulnerable citizens. Being (self)critical reflexively (TAKAKI, 2019, 2020 ) is requested here for risks are inherent to critical literacy. Some subject matters may be more delicate and some parents, students, teachers might resist or resent discussing them. In this case, listening to them and creating alternatives with the help of other transdisciplinary professionals to deal with such issues from an educational and social-cultural perspective might be a way out.

Thus, critical literacy seeks to problematize the problematizations already elaborated on issues closely related to race, gender, class, religion, to name a few and go beyond through devising options. Tensions, paradoxes and divergences are expected as a sign of richness in the debates and they should not be erased. The aim is to understand the historical motives that make one think, feel, behave and act in particular ways, and not in others. The same procedure applies to me, to us in intertwined fashion (FREIRE, 2005). This is what I call continuous reflexive (self)critique (TAKAKI, 2019, 2020). Reexamining this complex social experience within uneven relations of meanings and power under limited conditions and modest logics and the way it gains significance in specific contexts seems pivotal for critical literacy.

Due to the fact that we cannot be the other, speak for the other, act for the collective other, new investigations are needed to foster comprehension of the unknown meanings from its/his/her/their perspective(s). For instance, debating who can access online emergent education and who cannot entails asking questions like this one: What citizens are desirable for pandemic and post-pandemic times regardless of having or not access to

\footnotetext{
${ }^{13}$ In pandemic times, isolated cases shown by social media include some Mayors of small towns with teachers working together to prepare pedagogical materials and bring them to students, whose families cannot afford to pay for equipment and Internet access. Other times, on an individual level, teachers leave the materials available in his/her house so that parents can take them away to their children.
} 
the Internet? The ones: a) open to the diverse other; b) able to take initiative to strategically create options; d) who expand on intersubjective, discursive and transssemiotic, translingual, post-human and sustainable horizons, ecologically; e) who pose challenging questions to weaken hegemonic attitude, discourses towards the empowerment of minoritized groups; f) who exercise "affirmative capacities which acknowledge the importance of limits" (BRAIDOTTI, 2019, unpaged) and g) who are with (FREIRE, 2005) and for the enigmatic other (LEVINAS, 2008) as an incessant process of becoming.

Nonetheless, such a process does not go without reflexive (self) critique (TAKAKI, 2019, 2020) to avoid falling into the trap one criticizes. For the sake of illustration, what the laws of the State dictate should not be permanent facts or conditions reinforcing systems of hegemony founded on "three central elements which affect the daily life of the world's population: coloniality of power, capitalism and eurocentrism"14 (QUIJANO, 2005, p. 124) or "the matrices of modern/colonial/capitalist power as Walsh (2018, p. 76) argues. According to Braidotti (2018, p. 182) it is important to ask "What does it tell you about yourself that you are classified as female, white, middle-class, or LGBT? Is all very useful, and yet not, because what matters to nomadic and posthuman understanding is what kind of ethical subject you are."

This set of critical interrogations converges to another point: irrespective of some teachers and parents' credit, one should not forget that equitable access to technology with adequate broadband is tied to power relations implicated in socio-economic and cultural features. The tech giants, such as Apple, Amazon, Facebook, Microsoft and Google are evidence of domination compelling us to exercise critical literacy within the neoliberal colonization, as The Social Dilemma shows. Access to the material, content and social relations within emergent lessons cannot do without the understanding of how diverse online platforms try to place people as subalternized subjects, second-class citizens and products to acritically consume meanings, materials and service.

Socio-economic privilege on the part of some families does not necessarily signify conscious resistance to and transformation of the

\footnotetext{
${ }^{14}$ Our translation from: três elementos centrais que afetam a vida cotidiana da totalidade da população mundial: a colonialidade do poder, o capitalismo e o eurocentrismo.
} 
dominant market, masculinities, racial discrimination, multi-sited violence, that is, social inequality. On the contrary, oppressive institutional forces and social relationship continue shaping our experiences, a concern for all.

Opening up intersectional windows within multisensorial meaning making for identity reconstruction and collective agency together with the adversaries (MOUFFE, 2013), instead of mere enemies helps amplify interconnections. The idea is not to get stuck with colonialism, patriarchicalism and capitalism (SANTOS, 2002, 2018, 2020). Central will be the ability of the Global South to strategically renegotiate with the radical colonizers from the Global North, following Santos (2018). On behalf of sustainability, as we-they depend on the resources of the planet, social justice (FRASER, 2000) in its broader sense can/should be enacted. In order to transform subordination in capitalist societies, Fraser (2000) proposes alternative politics of recognition and distribution of resources. Recognition of differences means applying the same status white men have to black women in important decisions at work, for example. Putting it differently, "parity of participation" (FRASER, 2000, p. 115) and institutional compliance with such women's legitimized full partnership are high on the agenda to mitigate the problems with a view to minimize the consequences of social injustice.

This brings us to another key point: entanglement. Entanglement means that a great deal of daily effort will be necessary for us-them to learn from indigenous social practices, characterized by decolonial, horizontal relations traversing boundaries, making forays into unresolved dialogues, collaboration, healthy solidarity. "It is necessary, thus, that we learn to learn [...] No one writes if he/she does not write, as no one swims if he/she does not swim", ${ }^{15}$ Freire (2001, p. 267) argues. I complement: no one navigates if he/she does not navigate within "digital epistemology" (LANKSHEAR; KNOBEL, 2002, p. 5) or "performance epistemology” (LANKSHEAR, KNOBEL, 2011, p. 11).

Challenging hegemonic attitude, discourses towards the inclusion of polissemic voices and life trajectories might start empowering minoritized groups. Critical and digital literacies are constantly evolving as a way of re-educating ourselves with the other (FREIRE, 2005), for the other

\footnotetext{
${ }^{15}$ É necessário, então, que aprendamos a aprender [...] ninguém escreve se não escrever, assim como ninguém nada se não nadar.
} 
(LEVINAS, 1991, 1994, 2000, 2007, 2008, 2014) politically, culturally, socially, economically as a flourishing social practice (STREET, 1984). It goes without saying that Freire's legacy was cultivated with the other and for the other.

This educational, philosophical and political task is not free of barriers, though. Todd (2003), conceives of education as a violent institution metaphorized as an imperfect garden. On being open to the other, the teacher becomes a learner. To illustrate this point, she provides us with the example of a teacher who lends winter clothes to a vulnerable student. This gesture carries mixed feelings, such as: modesty, humility, control, violence and gratitude. Translating ethics is desirable and needed here. Ethics is the self's capacity to respond to altruism with non-altruism bringing in the other's responsibility to come to terms with the self. Not unlike Todd (2003), Janks (2010), understands critical literacy as the people's ability to read with and against the author. If the reader is the other, this means the self is called upon to exercise agency while attributing meanings to alterity in the reading process. An active reader is expected to reconstruct the historical world in consonance with the Bakhtinian notion of heterogeneous, political and dynamic language.

The inside-outside contexts might amplify our awareness of our histories, a condition for possible collective gradual societal transformations. I say our, on account of the contamination of the locus of enunciation (BHABHA, 1994) from/with which you construct meanings (the Freirean $t u$ in Portuguese) with the socio-historic context from/with which myself (the Freirean eu or de mim in Portuguese) speak. As difference (the Freirean contrary and the Levinasean alterity) permeates both contexts of dialogue within specific transcultural, educational, political, transsemiotic, economic, human, non-human and inhuman (BRAIDOTTI, 2006, 2018, 2019), technological, cosmological, spiritual, spatial-temporal aspects, conflicts, paradoxes are inherent to the proximity. The proximity and distance for Levinas $(2000,2008)$ sustained by otherness (you) and sameness (me) accompany any process of transformation and "change is collective, social [...] All of us have to assume responsibility in the general process of change" ${ }^{16}$ (FREIRE, 2005, p. 270). In this way life-long learning (ALHEIT,

\footnotetext{
${ }^{16}$ Our translation from: mudança é coletiva, social [...] todos nós temos de assumir responsabilidade no processo geral de mudança.
} 
2018) entails critical literacy with and for the other, the dynamic, situated, entangled human, non-human and inhuman (BRAIDOTTI, 2018, 2019) beyond online/offline (post)pandemic times.

Staying in the world with the world in Freire's engagement in life (2005, p. 251) is extended by staying in the world with the world for the world in my interpretation of ethics as "the-one-for-the-other, which is the very birth of signification beyond being" (LEVINAS, 2008, p. 90), whose apprehension is possible under the sign of a "trace", (LEVINAS, 2008, p. 91). In other words, social justice brings about the recognition that difference/alterity enhances the possibility of ethics/social justice if constructed with the other (FREIRE, 2005), for the other (LEVINAS, 1991, 1994, 2000, 2007, 2008, 2014). The other changes me/myself each time the encounter with otherness creates space for learning, unlearning and relearning from/with/ against/for the other. The other for Fraser (2000) can be the vulnerable black woman with the same legitimized "parity of participation" (p. 115) as the hegemonic white man to come to terms in socio-political decisions. The other for Braidotti $(2006,2018,2019)$ is the human, non-human, inhuman as becoming. It is in the hope that other (e.g.: the Global North) can/should be contaminated in Freirean mode and learn with and for the decolonial Global South to mitigate the impact of pluralized violence in the universe. However, reciprocity and mutuality are up to the other in Levinasian ethics, and in this way, the radical Global North may or may not correspond to the decolonized Global South's needs in different temporal-spatial logics. As previously mentioned, the other is a condition for the self's life-long learning (ALHEIT, 2018) and participative social collective agency.

Clearly, reinventing life reexisting with and for the other has become evident in pandemic times. And, revisiting critical literacy, in this expanded way, has the potential to shorten the distance between the have and havenots and reduce the impact of social inequities, which are the products of the exploration of capitalism. One agent who is at the front line in this endeavor is the teacher. Investing in continuous teacher education is a possibility of transdisciplinary, transcultural and reflexive (self)critical (TAKAKI, 2019, 2020) ethics. This argument seeks support in Levinas' traces of ethics, which is the subject matter of the subsequent section. 


\section{The (absolutely) other matters ${ }^{17}$}

One can see this nostalgia for totality everywhere in Western philosophy, where the spiritual and the reasonable always reside in knowledge.

(LEVINAS, 2000, p. 76)

So far we have been hinting that collective actions through cyberactivism matter for social justice. The incorporation of the Internet into educational spaciality in social movements and projects to advocate in favor of the minoritized groups, to influence voters' decisions have been impressive for the last few years in big cities and countries around the world.

Crucially, one possible way to exercise micro-resistance agency informed by critical literacies is preparing teachers to become mediators to enhance their students' capacity for problematizations of taken-forgranted perspectives. This educational perspective means scrutinizing the paradoxes and dilemmas of the very act of complicating the ethical issues under discussion. Exploring routes with fresh eyes might prevent one from reproducing pre-conceived ideas and prejudice towards the other. Much before the proximity of the other, the responsibility of the self is there, as Levinas (2008) teaches us. Being open to otherness is key. "And me, whoever I may be, but as a 'first person', I am he who finds the resources to respond to the call.” (LEVINAS, 2000, p. 89). The call is the responsibility for the other. The other can be online/offline learning. Prioritizing the other means "before an open door, 'After you, sir!" (p. 89) reinforcing the following: "First philosophy is an ethics" (p. 77). Ethics in this way is constant becoming otherwise implied in infinite alterity in the openness of the self to the other.

Embarking on the understanding of the other is an ethical dynamic and educational exercise. Levinas' (2008) is not worried about constructing a theory of ethics per se. Instead, distancing from the absolute Westernized thought, which places being as concrete, visible and homogeneous, is part of his endeavor. Also, decolonizing philosophy (MALDONALDO-TORRES, et al., 2018, p. 65), searching for meanings within alterity are central in his project of ethics as a trace. Hence the relation to/for the other is ethical on

\footnotetext{
${ }^{17}$ It is not my aim here to provide a comprehensive theorization of ethics but to leave some traces so that the readers might catch uncontainable spirits of it.
} 
account of alterity. "Face and discourse are tied. The face speaks. It renders possible and begins all discourse." (LEVINAS, 2000, p. 87). And, this raises a question. What is language for the cited philosopher?

Language is thus not reducible to a system of signs doubling up beings and relations; that conception would be incumbent on us if words were nouns. Language seems rather to be an excrescence of the verb. [...] The lived sensation, being and time, is already understood in a verb... But language is also a system of nouns. Denomination designates or constitutes identities in the verbal or temporal flow of sensation. Through the opening that temporalization works in the sensible, disclosing it by its very passing, assembling it by retention and memory $[\ldots .$.$] , the word identifies 'this as that', states the$ ideality of the same in the diverse. (LEVINAS, 2008, p. 35).

In suggesting that language behaves like a joker, as a verb and a noun, its users and creators ressignify their narratives, experiences, memories in the same way ethics does. Ethics for the other, thus, recognizes sameness and alterity as intertwined without one suffocating the other. It seems evident that the ambiguity between the verb and the noun is necessary for ethics as becoming. Ethics as "responsibility for another is precisely a saying prior to anything said... is an interruption of essence", as Levinas explains (2008, p. 43). Responding to another by saying does not exhaust in this manifestation. Saying means otherwise than essence, prior to objectification in the form of a response to the other.

Saying states and thematizes the said, but signifies it to the other, a neighbor, with a signification that has to be distinguished from that borne by words in the said. This signification to the other occurs in proximity. Proximity is quite distinct from every other relationship, and has to be conceived as a responsibility for the other; it might be called humanity, or subjectivity, or self. (LEVINAS, 2008, p. 46).

Following his reasoning, the other is infinitely otherness, which is radical alterity within immanence - at the risk of being repetitive-. Such an alterity cannot be surpassed. The self is responsible for the other in a state of vulnerability (LEVINAS, 2008) with no choice left. Such a responsibility is imposed before any encounter with the other. "The passivity of the 
one is a passivity more passive still than all the passivity of undergoing" (LEVINAS, 2008, p. 57) "to the point of becoming an inspiration, that is, the alterity in the same" (LEVINAS, 2008, p. 67). I understand the other can be a collective he $/$ she $/ \mathrm{it},{ }^{18}$ human, nonhuman (BARAD, 2007), visible, invisible. What matters is the idea of alterity from which the self cannot escape. Contesting this obligation is out of the question when the self is compelled to assume the uncertainties within alterity, resembling "digital epistemology" (LANKSHEAR, 2003, p. 5) or "performance epistemology" (LANKSHEAR, KNOBEL, 2011, p. 11).

The obligation of the self for the other is pre-given. It precedes any form of language and questioning and, as such, ethics characterizes "first philosophy" (LEVINAS, 2008), always in debt to the other. No self is left out in the ethical trace, and to make matters worse, it is impossible to substitute this responsibility for the other by another task. This expands the concept of the self as a hostage of the other. Rather than being inactivity, the other summons the self to accept work. Embarking on this project is neither a choice, nor an accident. The face of the other is an imperative just like the air for breathing.

Neither does alterity permit my/the self(ves) to control myself/ herself/himself/itself/themselves/ourselves nor does it regulate the other. It is a daily effort to understand that meanings abound in apparent sameness. The event of subjectivity occurs in the exposure to the other. "The subjectivity as the other in the same as an inspiration, is the putting in to question of all affirmation for-oneself" (LEVINAS, 2008, p. 111). In other words, being responsible for the other represents an opportunity to question the self's own assumptions in confrontation with the alterity emerged from/with/against/by/for the other, a Freirean lesson. Under such premises, reflexive (self)critique (TAKAKI, 2019, 2020) is based.

Responsibility "from-the-other is already for-the-other [...]. This responsibility is prior to dialogue, to the exchange of questions and answers, to the thematization of the said, which is superposed on my being put into question by the other in proximity," claims Levinas (2008, p. 111). It is to be reconstruced permanently, that is why the self's desire to thoroughly grasp and understand every single thing, every single person is not particularly useful bearing in mind not all meanings are communicatively intelligible and

${ }^{18}$ It might be the online/offline life-long learning processes. 
possible (not yet). In other words, some entities are only felt, manifested but not possible to be conveyed by means of conventional language. It functions as though the self is left adrift within meanings that overflow in their own right. When contextualized, they miss/lose/postpone more than the self can apprehend and express. The same analogy applies to online/offline learning in (post)pandemic times and beyond that. This, in turn, seems to be a form of humility as the limited capacity of the self (e.g., schools, teachers, parents) within the impossibility of abdicating to alterity (e.g., students, digital platforms, institutions, curriculum design). There is no way out unless face the other. The notion of a limited self is useful in the permanent struggle for meanings entangled with otherness in order for the self to rethink, feel, teach, learn, unlearn and act/enact otherwise.

Transposing ethics as a trace to the realm of the "digital epistemology" (LANKSHEAR, 2003, p. 5) or "performance epistemology" (LANKSHEAR, KNOBEL, 2011, p. 11) towards online/offline teaching, learning, unlearning otherwise, in (post)pandemic times, presupposes that otherness is infinite alterity, an unattainable target and because of that, it should be dynamic or else, "a constant use of the verb being" (LEVINAS, 2008, p. 155) instead of an essence. From this prism, alterity cannot be domesticated and homogenized. Preliminarily, alterity and language were 'put' there. The self did not create them. They are pre-conditions of a possible world; a world of becoming and, transforming otherwise, just like social justice otherwise. This is not a matter of everything goes. Conventions and norms inform "the condition - or the uncondition" (LEVINAS, 2000, p. 100) under/within which a possibility of proximity of the other emerges. Taking initiative to make a move can be postponed, but not eliminated "The neighbor assigns me before I designate him.” (LEVINAS, 2008, p. 87).

The self, as host, welcomes the guest and she/he/it is at the same time her/his/its a guest received in her/his/its own house. Opening the house means being invited by her/his/its own guest. This is artificial but necessary, as hospitality precedes property, paraphrasing Derrida (2015, p. 58-61). Going further, this is translated as beyond being, the otherwise than being having hospitality as infinitely unconditional. The language of ethics is, thus, possible if subjectivity is understood as responsibility for the other: "the subject is a guest" (p. 72) and a "the guest is a hostage as a subject under question, obsessed (therefore besieged), persecuted, in the very place where he has a place, there, where, emigrated, exiled, foreigner, guest always, he 
finds himself domiciled before electing domicile” (DERRIDA, 2015, p. 73). "It is to be like a stranger, hunted down even in one's home, contested in one's own identity", reinforces Levinas (2008, p. 92).

"The difference between the Same and the Other is the nondifference for the other or fraternity [...] suspension for-itself, the for-the-other of my responsibility", as Levinas stresses it (1991, p. 7). The intersubjective relationship does not count on reciprocity or symmetry. "I can substitute myself for everyone, but no one can substitute himself for me." (LEVINAS, 2000, p. 101).

As any other theoretical framework, the "philosophy" of ethics elaborated on by Levinas (2008) has its limitations, which he himself admits. The good side of going through his readings is the recognition that theories are trapped in the authors' context and perceptions. In addition to this, understanding language limitations is already an ethical trace.

Caputo (2006) is heavily influenced by Derrida and he claims theories cannot be subsumed to pre-established principles. Resorting to deconstruction (DERRIDA, 1997), he perceives warning and more caution on the way to conceptualize ethics. Certainties of Enlightenment would be dangerous ethics. Symmetrical and concrete conceptions based on measurable criteria resonating Western philosophy are questioned. Rejecting such a tradition, Caputo (2006) claims that justice (the term he uses) can only be conceived of under deconstructible conditions that solicit us not to jettison the norm but "to reinvent the rule under the pressure of the present situation $^{19}$ (CAPUTO, 2006, p. 138). Hence, "theorizing" justice cannot be put in a nutshell. It is a call for different sources, perspectives, in ways that makes assumptions softened, enigmatic, and perpetually questionable. "Obligations do not derive from some central source of power. Obligations are strictly local events, sublunary affairs, between us. They are matters of flesh and body, without cosmic import or support. They happen." (CAPUTO, 1993, p. 227). In this vein, responsibility as obligation with reference to deconstruction is always already a possibility of justice. Quoting Derrida (1992), Caputo (2006, p. 131-133) writes:

\footnotetext{
${ }^{19}$ This rings a bell: the constant reinvention (becoming) of online/offline learning with and for the other as ethics/social justice.
} 
justice, if such a thing exists, is not a thing. Justice is not a present entity or order, not an existing reality or regime $[\ldots]$. Justice is the unforeseeable prospect (a paralyzing paradox) in virtue in which the things that get deconstructed are deconstructed [...]. It (deconstruction is possible as an experience of the impossible, there where, even if it does not exist (or does not yet exist, or never does exist), there is (ily a) justice. (our emphasis).

It is perceived that Caputo (2006) recognizes the self's limitations. Lying too much emphasis solely on the self's duty in relation to the other prevents a myriad of evolving singularities.

For the near future, approaching the other through deconstructing the deconstruction of "First philosophy" (LEVINAS, 2000, p. 77) seems to be a social summon to approach ethics. This can be explained by "I do not believe, however, that pure philosophy can be pure without going to the 'social problem"' (LEVINAS, 2000, p. 56). The ever-lasting social inequities have divided Brazil into the haves and the have nots (with alterity in each interior). And, if alterity is a pre-condition of ethics, before entering Brazil, technology, and the COVID-19 pandemic require more responsibility and hospitality on our part as citizens of a broader society. The alterity of alterity entices a pluralist and complex mode of being, which I understand as beingand-not-being simultaneous and enigmatically.

Seeing in this way, sustainability, safe drinking water, health care and food, safety, routine, respect, education, future perspectives are like Derridian singularities and closer to the affirmative ethics, in Braidotti's view (2019, unpaged).

Affirmative ethics is a collective practice that acknowledges the passing and dying of multiple universes, grounded in embedded and embodied materialist practices [...] including knowledge generated by far older Indigenous epistemologies.

The generative force of life, which is zoe (BRAIDOTTI, 2018, 2019), implied in the previous citation, actualizes otherness resembling postanthropocentric and eco-philosophical perspectives. Here, transformations of negative becoming into positive without being naive allows us to "speak of a self as a transversal relational entity within collective transselves". (BRAIDOTTI, 2018, p. 183). They all matter for the self and for the 
other. "The singular is what is always an already overlooked, out of sight, omitted, excluded, structurally, no matter what law, no matter what universal schema is in place", comments Caputo while quoting Derrida (1992) (apud CAPUTO, 2006 p. 135). The State sees itself in front of the human, nonhuman and inhuman other(s) with no possibility whatsoever of turning its back to responsibility concerning such singularities. Students, teachers, parents, authorities, policy makers, other professionals and the historically missing people (black people, indigenous communities, women, children, homoaffective people, to mention a few) as Braidotti claims (2019) are the social other with whom (FREIRE, 2005) for whom (LEVINAS, 2008) critical literacy as an ethical enigmatic becoming can be envisaged. "The difference between the Same and the Other is the nonindifference for the other of fraternity" (LEVINAS, 1991, p. 7), be it in COVID-19 pandemic, be it in post-pandemic times. To broaden ethical literacy, the complex self ends up being an open (in)hospitable space in movement for educators, together with the State, authorities, policy makers, curricula designers, students, parents, community members, non-humans (e.g., digital tools) and inhumans to reimagine other travels.

Approaching the end of this article, some of the principles for ethics/ social justice otherwise are here summarized:

a) A more nuanced view of language to read words and worlds (FREIRE, 2005);

b) The relationship between the self and the other presupposes alterity (LEVINAS, 1991, 1994, 2000, 2007, 2008, 2014);

c) Ethics with the other (FREIRE, 2005) and for the other (LEVINAS, $1991,1994,2000,2007,2008,2014)$ in ways that neither the self nor the other imposes sameness onto each other;

d) The other is collective, human, non-human, inhuman (BRAIDOTTI, 2019, unpaged), complex, situated but also enigmatic;

e) Zoe as "the ability to process pain and construct an ethical subjectivity worthy of our times", Braidotti (2019, unpaged);

f) Hospitality (DERRIDA, 2015) in the face of the other is ambiguous;

g) The self's responsibility for the other as vulnerability, passivity, and a call suggests an opportunity for learning, unlearning, relearning, acting/ enacting otherwise within alterity and reflexive (self)critique (TAKAKI, 2019, 2020); 
h) The otherwise than being (LEVINAS, 2008) might undermine Westernized colonial techno-capitalism;

i) War presupposes peace;

j) Decolonizing the decolonial posthuman first philosophy remains a challenge.

k) Critical literacy can be ressignified though exposing the partiality of all truth claims and the inscription of differences from/with/against/for the other in digital (LANKSHEAR; KNOBEL, 2011) and less digital spaces.

1) Alterity evinces hope/possibility of ethics within infinite otherness.

\section{Final words}

Given the past, present and future circumstances in contemporary and more or less digital society, a chance for ethical relations between the self and the other operates under the sign of a trace. Transgressing boundaries and changing deep-seated beliefs and habits related to technology, critical literacy and ethics/social justice are some of the compelling reasons for us to get busy with the other for the other. In pandemic times, practicing physical distance, wearing a mask and applying alcohol gel are examples of ethics for the collective other and also for the self. Nevertheless, the proximitydistancing amidst uneven relations of power in local-global, transcultural entangled human, non-human, inhuman coexistence goes much beyond such a practice.

A paradigm ethical shift infusing the self with a pluralistic orientation to understand the complex collective other, often shaped and framed by globalized discourses, is indispensable to reposition vulnerable/missing people's values in knowledge reconstruction and in societal changes. Being with and for the other entails openness, beauty, porosity and creative potential to appreciate and work on critical literacy otherwise as life-long learning. 


\section{References}

ALHEIT, P. The Concept of "Biographicity" as Background Theory of Lifelong Learning? Adult Education Discourses, Zielona Góra, Polonia, v. 19, p. 9-22, 2018. Available at: http://cejsh.icm.edu.pl/cejsh/element/bwmeta1.element.desklight7bd3d37b-f76e-495b-b98c-f3c1626a50ea. Access on: Sept. 28, 2020.

BARAD, K. Meeting the Universe Halfway: Quantum Physics and the Entanglement of Mater and Meaning. Durham, N.C.: Duke University Press, 2007. DOI: https:// doi.org/10.1515/9780822388128

BHABHA, H. The Location of Culture. London, New York: Routledge, 1994.

BRAIDOTTI, R. Posthuman Knowledge. Cambridge: Polity Press, 2019. Kindle version.

BRAIDOTTI, R. Affirmative Ethics, Posthuman Subjectivity, and Intimate Scholarship: A Conversation with Rosi Braidotti. In: STROM, K.; MILLS, T.; OVENS, A. (ed.). Decentering the Researcher in Intimate Scholarship. Wagon Lane, UK: Emerald Publishing, 2018. p. 179-188. DOI: https://doi.org/10.1108/S1479368720180000031014

BRAIDOTTI, R. Transpositions. On Nomadic Ethics. Cambridge: Polity Press, 2006. CANAGARAJAH, S. Reconsidering Material Conditions in Language Politics: A Revised Agenda for Resistance, Nordic Journal of English Studies, Gothenburg, Sweden, v. 19, n. 3, p. 101-114, 2020. DOI: http://doi.org/10.35360/njes.580

CANAGARAJAH, S. Introduction. The Nexus of Migration and Language. The Emergence of a Disciplinary Space. In: CANAGARAJAH, S. (ed.) The Routledge Handbook of Migration and Language. London; New York, 2017. Kindle version (unpaged).

CANAGARAJAH, S. Translingual Practice. Global Englishes and Cosmopolitan Relations. London; New York: Routledge, 2013. DOI: https://doi.org/ 10.4324/9780203073889

CAPUTO, J. (ed.) Deconstruction in a Nutshell. A Conversation with Jacques Derrida. Edited and with a Commentary by John D. Caputo. New York: Fordham University Press, 2006.

CAPUTO, J. (ed.). Against Ethics. Contributions to a Poetics of Obligation with Constant Reference to Deconstruction. Indiana: Indiana University Press, 1993. (Studies in Continental Thought). DOI: https://doi.org/10.2307/j.ctv15d7z9r 
DELEUZE, G.; GUATTARI, F. A thousand Plateaus: Capitalism and Schizophrenia. Translation and Foreword by Brian Massumi. Minneapolis: University of Minnesota Press, 2005.

DERRIDA, J. Jacques Derrida. Adeus a Emmanuel Lévinas. Tradução de Fábio Landa com a colaboração de Eva Landa. São Paulo: Perspectiva, 2015.

DERRIDA, J. Of Grammatology. Translated by Gayatri Chakravorty Spivak. Baltimore, Maryland: The Johns Hopkins University Press, 1997.

DERRIDA, J. Force of Law. The Mystical Foundation of 'Authority' In: CORNELL, D.; ROSELFELD, M.; CARLSON, D. G. (ed.) Deconstruction and the Possibility of Justice. New York: Routledge, 1992. p. 3-167.

FRASER, N. Rethinking Recognition. New Left Review, London, v. 3, p. 107-118, 2000. Available at: https://newleftreview.org/issues/ii3/articles/nancy-fraserrethinking-recognition. Access at: Jul. 12, 2020.

FREIRE, P. Pedagogia da tolerância. São Paulo: Editora da UNESP, 2005.

FREIRE, P. Carta de Paulo Freire aos professores. Estudos Avançados, São Paulo, v. 15, n. 42, p. 259-268, 2001. DOI: https://doi.org/10.1590/S010340142001000200013. Disponível em: https://www.scielo.br/pdf/ea/v15n42/ v15n42a13.pdf. Acesso em: 4 de jul. 2020.

JANKS, H. Literacy and Power. London; New York: Routledge, 2010. DOI: https:/ / doi.org/10.4324/9780203869956

LANKSHEAR, C. The Challenge of Digital Epistemologies. Education Communication and Information, [S.l.], v. 3, n. 2, p. 167-186, 2003. DOI: https://doi. org.10.1080/14636310303144

LANKSHEAR, C.; KNOBEL, M. New Literacies: Everyday Practices and Social Learning. Berkshire; New York: Open University Press, 2011.

LEVINAS, E. Violência do rosto. Tradução de Fernando Soares Moreira. São Paulo: Edições Loyola Jesuítas, 2014.

LEVINAS, E. Otherwise than Being or Beyond Essence. Translated by Alphonso Lingis. Pittsburgh, Pennsylvania: Duquesne University Press, 2008.

LEVINAS, E. Entrevistas. In: POIRIÉ, F. (ed.). Emmanuel Lévinas: ensaio e entrevistas. Tradução de J. Guinsburg, Márcio Honório de Godoy e Thiago Blumenthal. São Paulo: Perspectiva, 2007. p. 51-134.

LEVINAS, E. Ethics and Infinity. Conversations with Philippe Nemo. Translated by Richard A. Cohen. Pittsburg: Duquesne University Press, 2000. 
LEVINAS, E. Totality and Infinity. An Essay on Exteriority. Translated by Alphonso Lingis. Pittsburgh: Duquesne University Press, 1994.

LEVINAS, E. Whole otherwise. In: BERNASCONI, R.; CRITCHLEY, S. (ed.; trans.). Re-reading Levinas. Indiana: Indiana University Press, 1991. p. 3-10.

LUKE, A. Educational Policy, Narrative and Discourse. New York; London: Routledge, 2019. DOI: https://doi.org/10.4324/9781315145167

MALDONALDO-TORRES, N.; VIZCAÍNO, R.; WALLACE, J.; WE, J. E. A. Decolonizing Philosophy. In: BHAMBRA, G.; GEBRIAL, D.; NISANCIOGLU, K. (ed.). Decolonizing University. London: Pluto Press, 2018. p. 64-92.

MONTE MÓR, W. Formação docente e educação linguística: uma perspectiva linguístico-cultural-educacional. In: SILVA, W. M.; SILVA, W. R.; CAMPOS, D. M. (org.). Desafios da formação de professores na Linguística Aplicada. Campinas: Pontes Editores, 2019. p. 187-206.

MONTE MÓR, W. Sobre rupturas e expansão na visão de mundo: seguindo as pegadas e os rastros da formação crítica. In: PESSOA, R. R.; SILVESTRE, V. P. V.; MONTE MÓR, W. (org.). Perspectivas críticas de educação linguistica no Brasil. São Paulo: Pá de Palavras, 2018. p. 265-278.

MONTE MÓR, W. Sociedade da escrita e sociedade digital: línguas e linguagens em revisão. In: TAKAKI, N. H.; MONTE MÓR, W. (org.). Construções de sentido e letramento digital crítico na área de línguas e linguagens. Campinas: Pontes Editores, 2017a. p. 267-286.

MONTE MÓR, W. Letramentos críticos e expansão de perspectivas: diálogo sobre práticas. In: JORDÃO, C. M.; MARTINEZ, J. Z.; MONTE MÓR, W. (org.). Letramentos em prática na formação inicial de professores de inglês. Campinas: Pontes Editores, 2017b. p. 315- 336.

MONTE MÓR, W. Crítica e letramentos críticos: reflexões preliminares. In: ROCHA, C. H.; MACIEL. R. F (org.). Lingua estrangeira e formação cidadã: por entre discursos e práticas. Campinas: Pontes Editores, 2013. v.1, p. 31-59.

MONTE MÓR, W. Critical Literacies in the Brazilian University and in Elementary/ Secondary Schools: The Dialetics Between the Local and the Global. In: MACIEL, R. F.; ARAUJO, V. A. (org.). Formação de professores de linguas: ampliando perspectivas. Jundiaí: Paco Editorial, 2011. p. 307-318.

MONTE MÓR, W. Multimodalidades e comunicação: antigas novas questões no ensino de línguas estrangeiras. Letras \& Letras, Uberlândia, v. 26, n. 2, p. 469-476, 2010. 
MONTE MÓR, W. Critical Literacies, Meaning Making and New Epistemological Perspectives. Revistas UNAL. Matices en Lenguas Extranjeras, Bogotá, n. 2, [s.p.], 2008. MONTE MÓR, W. Linguagem e leitura da realidade: outros olhos, outras vozes. 1999. 288f. Tese (Doutorado em Estudos Linguísticos e Literários em Inglês) Departamento de Letras Modernas, Universidade de São Paulo, São Paulo, 1999.

MOUFFE, C. Agonistics. Thinking the World Politically. London; New York: Verso, 2013.

MUSPRATT, S.; LUKE, A.; FREEBODY, P. (ed.). Constructing Critical Literacies. Teaching and Learning Textual Practice. New York: Hampton Press, 1997. (Language \& Social Processes)

PENNYCOOK, A. From Speaking to Semiosis: In Search of Sociolinguistic Comprehensiveness. In: ABRALIN AO VIVO - LINGUISTICS ONLINE, 2020. Youtube. Available on: https:/ / www.youtube.com/watch?v=EmOs-ih7ftw. Access at: 8 Jul. 2020.

PENNYCOOK, A. Posthumanist Applied Linguistics. New York: Routledge, 2018. DOI: https://doi.org/10.4324/9781315457574

PENNYCOOK, A. Global Englishes and Transcultural Flows. London; New York: Routledge, 2006. DOI: https://doi.org/10.4324/9780203088807

PENNYCOOK, A.; MAKONI, S. Innovations and Challenges in Applied Linguistics from the Global South. London; New York: Routledge, 2020. DOI: https://doi. org/10.4324/9780429489396

QUIJANO, A. Colonialidade de poder, eurocentrismo e América Latina. In: LANDER, E. (org.). A colonialidade do saber: eurocentrismo e ciências sociais. Perspectivas latino-americanas. Ciudad Autónoma de Buenos Aires, Argentina: Clacso, 2005. p. 107-130. (Colección Sur Sur)

SANTOS, B. de S. A cruelpedagogia do vírus. Coimbra: Almedina, 2020.

SANTOS, B. de S. The End of the Cognitive Empire. The Coming of Age of Epistemologies of the South. Durham: Duke University Press, 2018. DOI: https:/ / doi.org/10.1215/9781478002000

SANTOS, B. de S. Para uma sociologia das ausências e uma sociologia das emergências. Revista Crítica de Ciências Sociais, Coimbra, v. 63, p. 237-280, 2002. DOI: https://doi.org/10.4000/rccs.1285. Available on: http://www. boaventuradesousasantos.pt/media/pdfs/Sociologia_das_ausencias_RCCS63. PDF. Access at: 7 Jul. 2020 
SCHMIDT, C. Language Policies and Language Education in Brazil and Canada: An Interview with Professor Schmidt. Interview by Daniel de Mello Ferraz. Papéis, Campo Grande, v. 24, n. 47, p. 206-216, 2020.

SOUZA, L. T. M. de Introduction. Theorizing the South(s). In: FINARDI, K. R. (org.). English in the South. Londrina: EDUEL, 2019. p. 87-24.

STREET, Brian V. Letramentos sociais: abordagens críticas do letramento no desenvolvimento, na etnografia e na educação. Trad. Marcos Bagno. São Paulo: Parábola, 2014.

TAKAKI, N. H. Por uma autoetnografia/autocrítica reflexiva. Interletras, Dourados, v. 8, n. 31, p. 443-462, abr./set., 2020. DOI: https://doi.org.10.29327/214648.8.3117

TAKAKI, N. H. É o que somos, sendo: o papel da (auto)crítica nos letramentos. In: FERRAZ. D. M.; KAWASHI-FURLAN, C. J. (ed.). Bate-papo com educadores linguísticos. letramentos, formação docente e criticidade. São Paulo: Pimenta-Cultural, 2019. p. 197-216. DOI: https://doi.org/10.31560/pimentacultural/2019.249.163-181

TAKAKI, N. H. Epistemologia-ontologia-metodologia pela diferença: lócus transfronteira em ironia multimodal. Trabalhos em Linguistica Aplicada, Campinas, v. 55, n. 2, p. 1-26, 2016. DOI: https://doi.org/10.1590/010318134907175031

TODD, S. Learning from the Other. Levinas, Psychoanalysis and Ethical Possibilities in Education. New York: State University of New York Press, 2003.

VOLÓCHINOV, V. (Círculo de Bakhtin). Marxismo e filosofia da linguagem. Problemas fundamentais do método sociológico na ciência da linguagem. Tradução, notas e glossário de Sheila Grillo e Ekaterina Vólkova Américo. Ensaio introdutório de Sheila Grillo. São Paulo: Editora 34, 2017.

WALSH, C. Interculturality and Decolonilaity. In: MIGNOLO, W.; WALSH, C. On decoloniality. Concepts. Analytics. Práxis. Durham; London: Duke University Press, 2018. p. 57-80. DOI: https://doi.org/10.1215/9780822371779-004

WITTGENSTEIN, L. Philosophical Investigations. Oxford: Blackwell, 1953.

Data de submissão: 28/9/2020. Data de aprovação: 16/2/2021. 